\title{
Economic Analysis of Domestic Electricity Production by Roof-Top Photovoltaic Systems in Two Provinces of Turkey
}

\author{
Ayten Özkök ${ }^{1}$, Önder Güler ${ }^{2}$
}

\begin{abstract}
Solar radiation of the location and applied incentives in the country are effective factors on photovoltaic system investments' feasibility. In this study, domestic electricity production by grid connected roof-top photovoltaic systems has been analyzed regarding to economic aspects. The two pilot provinces having the highest solar radiation in Marmara Region (Istanbul) and Mediterranean Region (Antalya) in Turkey were selected according to solar energy potential atlas (GEPA). As an autonomous load the average daily consumption of 11.45 $k W h$ was determined for a four-person household and roof-top photovoltaic systems with capacity of $3 \mathrm{~kW}, 4 \mathrm{~kW}$ and $5 \mathrm{~kW}$ were simulated by using HOMER software. It was analyzed whether or not conducted incentives in Istanbul and Antalya was sufficient and under what conditions roof-top photovoltaic systems investments were feasible. Roof-top photovoltaic systems investments in Istanbul and Antalya was economically not feasible due to pay back period of 16.0-16.8 years and 12.9-13.5 years respectively. Regarding to environmental issues photovoltaic systems with capacity of $5 \mathrm{~kW}$ in Istanbul and Antalya, reduction of $\mathrm{CO}_{2}$ emissions per detached house has been calculated around 3 tons and 3.5 tons respectively.
\end{abstract}

\footnotetext{
${ }^{1}$ Energy Institute

Istanbul Technical University,

Ayazaga Campus, 34469 ,

Maslak, Istanbul, Turkey

(e-mail: ozkokayten@gmail.com)

${ }^{2}$ Energy Institute,

Istanbul Technical University

Ayazaga Campus,34469,

Maslak, Istanbul, Turkey

(e-mail: onder.guler@itu.edu.tr)
}

\author{
Keywords \\ PV system, Solar radiation, Electricity Production, \\ HOMER, Turkey,
}

\section{Introduction}

As at the end of 2013, 30.6\% of total electricity production has been obtained from renewable energy sources (including hydroelectric power plants) in Turkey [1]. However, photovoltaic systems have constituted only $0.1 \%$ of this share $(30.6 \%)$. Compared to the EU countries, the grid-connected photovoltaic systems has been implemented approximately 10 years later in Turkey. In 1998, the first implementation of gridconnected PV system has took place with capacity of 4.8 kW by General Directorate of Electrical Power Resources Survey and Development Administration in Didim Province [2]

The potential implementation capacity of PV systems in Turkey is assumed as 450-500 GW regarding to annually solar radiation of 2738 hours [3]. Although Turkey has high solar energy potential, its investments on solar energy have stayed behind EU countries due to lack of infrastructural development and legal regulation gaps. According to statistics conducted by Unlicensed Electricity Generation Association (LI-DER), 1995 applications for PV systems having capacity of lower than $1000 \mathrm{~kW}$ have been accepted. The cumulative installations of PV systems having capacity of lower than $1000 \mathrm{~kW}$ have reached to $1.476 .823 \mathrm{~kW}$ by the end of 2014 [4].

In Turkey, photovoltaic systems are usually used for

This is an Open Access article distributed in accordance with the Creative Commons Attribution Non Commercial (CC-BY-NC-ND 4.0) license, which permits others to copy or share the article, provided original work is properly cited and that this is not done for commercial purposes. Users may not remix, transform, or build upon the material and may not distribute the modified material (http://creativecommons.org/licenses/by-nc/4.0/) 
A. Özkök, Ö. Güler
Economic Analysis of Domestic Electricity Production by Roof-Top Photovoltaic Systems in Two Provinces of Turkey

lighting of parks and gardens and traffic signals and in rural areas where the electricity distribution systems are not available. Regarding to cumulative installed capacity of PV systems in Turkey, the current situation has been assessed and the projection of coming years has been made by Vice president of International Solar Energy Society -Turkey Section (GUNDER) Mr Osman Özberk given in Figure 1 [5].

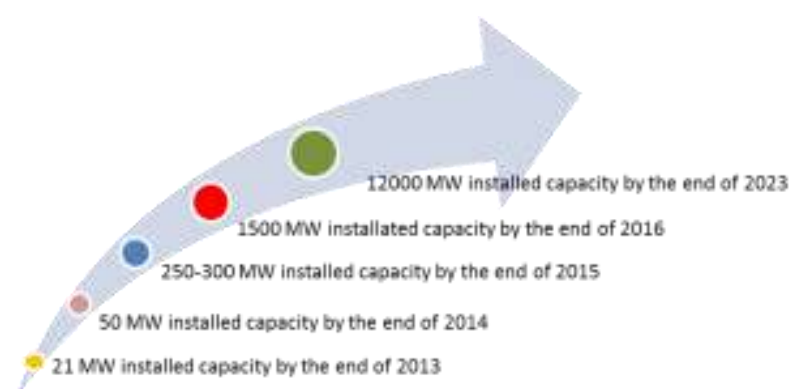

Fig. 1 The current situation of installed capacity of PV systems in Turkey and their projection of coming years

\section{Incentives mechanisms in Turkey}

In order to increase renewable energy share in the electricity production, legislations including Turkish national incentives mechanisms are given in Figure 2. For the first time, feed-in tariff and special discounts for generation of electricity from renewable resources have been put into practice by The Law No. 5346 on the Use of Renewable Energy Resources for Generating Electricity dated 10/05/2005 [6]. Within this law, the feed-in tariff will be the average marketing price of previous year determined by Energy Market Regulatory Authority (EPDK). Moreover, $50 \%$ discount on permits, lease, and servitude right related with state-owned land allocation will be implemented whereas exemption from paying the forestation and erosion control revenue and the forest villagers' development revenue will be provided. The feed-in tariffs will be valid for 7 years and can be increased by Council of ministries to $20 \%$ (as a maximum) annually.

The Ministry of Energy and Natural Resource has enacted Energy Efficiency Law numbered 5627 and dated $18 / 04 / 2007$ which identify the range of feed-in tariff (5 Euro cent $/ \mathrm{kWh}-5.5$ Euro cent $/ \mathrm{kWh}$ ) to be determined by EPDK annually. Within the law, the validity of the feedin tariffs has been increased to 10 years whereas the discount on permits, lease, and servitude right related with state-owned land allocation has been increased to $85 \%$ [7]. In addition, electricity generation facilities using renewable resources are exempt to obtain license if their capacity is equal or lower than $200 \mathrm{~kW}$ and they are using the produced electricity for their own needs.
Without considering of purpose of usage, the license exemption for electricity generation facilities using renewable energy resources has been put into practice in line with Electricity Market Law numbered 5784 and dated $09 / 07 / 2008$ if their capacity is equal or lower than $500 \mathrm{~kW}[8]$.

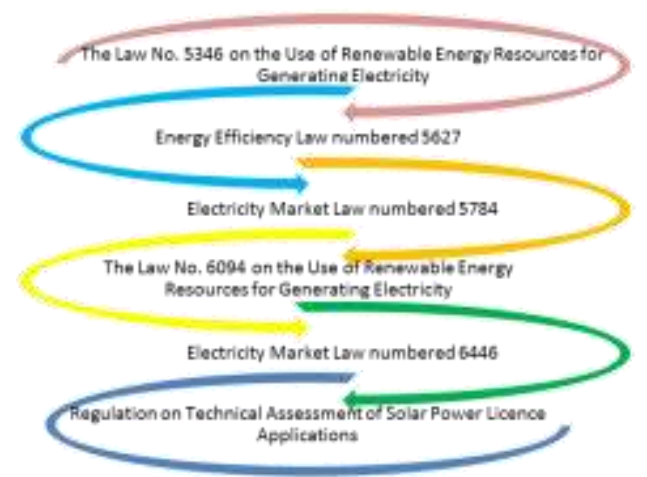

Fig. 2 Turkish Legislations including incentives mechanism

Within the Law on the Use of Renewable Energy Resources for Generating Electricity numbered 6094 and dated 29/12/2010, the feed-in tariffs has been increased and determined regarding to type of renewable energy resource. Additional incentives which is valid for 5 years has been also provided if the identified components of systems are manufactured in Turkey. The incentives provided by the Law numbered 6094 are summarized in Table 1 [9]. The maximum available incentives for 5 years is $20 \mathrm{US} \$$ cent $/ \mathrm{kWh}$ if the selected mechanical or electromechanical components are manufactured in Turkey.

Table 1 The incentives provided by the Law numbered 6094

\begin{tabular}{|c|c|c|c|}
\hline & Incentive & Detal & Valudity \\
\hline \multicolumn{2}{|c|}{$\begin{array}{l}\text { Feed-in tanfffs for electricty geberated } \\
\text { from solac energy }\end{array}$} & $13.3 \$$ cent $k$ Whout & Up 1010 yeat \\
\hline \multirow{5}{*}{ 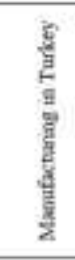 } & $\begin{array}{l}\text { Production of PV Panel } \\
\text { Integration and Solar } \\
\text { Structural Mechanics }\end{array}$ & 0.85 cent $k$ Whour & \multirow{5}{*}{ Up to 5 year } \\
\hline & PV modules & $135 \mathrm{cem} k$ kWhour & \\
\hline & $\begin{array}{c}\text { Cells Constivuting the PV } \\
\text { Modules }\end{array}$ & 3.55 ceat KWWout & \\
\hline & Inventer & 0.68 cent $k$ Whour & \\
\hline & $\begin{array}{l}\text { Material co the PV } \\
\text { Module that Focuses Solar } \\
\text { Ray }\end{array}$ & 0.59 cent kWbour & \\
\hline
\end{tabular}

The license exemption for electricity generation facilities with capacity of equal or lower than $1000 \mathrm{~kW}$ has been put into practice in line with Electricity Market Law numbered 6446 and dated 14/03/2013 [10]. The Ministry of Energy and Natural Resource has enacted Regulation on Technical Assessment of Solar Power License Applications which aims to identify procedures and principles for technical assessment.

Solar radiation of the location and applied incentives in the country are effective factors on photovoltaic system investments' feasibility. In this study, domestic electricity production by grid connected roof-top photovoltaic systems has been analysed regarding to economic aspects. The two pilot provinces having the highest solar radiation 
A. Özkök, Ö. Güler

in Marmara Region (Istanbul) and Mediterranean Region (Antalya) in Turkey were selected according to solar energy potential atlas (GEPA). As an autonomous load the average daily consumption of $11.45 \mathrm{kWh}$ was determined for a four-person household and roof-top photovoltaic systems with capacity of $3 \mathrm{~kW}, 4 \mathrm{~kW}$ and $5 \mathrm{~kW}$ were simulated by using HOMER software. It was analysed whether or not conducted incentives in Istanbul and Antalya were sufficient and under what conditions roof-top photovoltaic systems investments were feasible. Systems having payback period of 7 years and below were considered as favourable investments. In order to decrease payback period, different scenarios including increasing feed-in tariff $(25 \%, 50 \%, 75 \%$ and $100 \%)$, decreasing initial cost $(25 \%$ and $50 \%)$ and both of them were evaluated.

\section{Data of İstanbul and Antalya Provinces}

Solar energy potential atlas (GEPA) of Turkey prepared by General Directorate of Renewable Energy is given in Figure 3. In order to assess the impacts of solar radiation on pay back period of photovoltaic systems, Istanbul province located in north region and Antalya province located south region have been selected since the solar radiation value is increasing from north region to south region in Turkey.

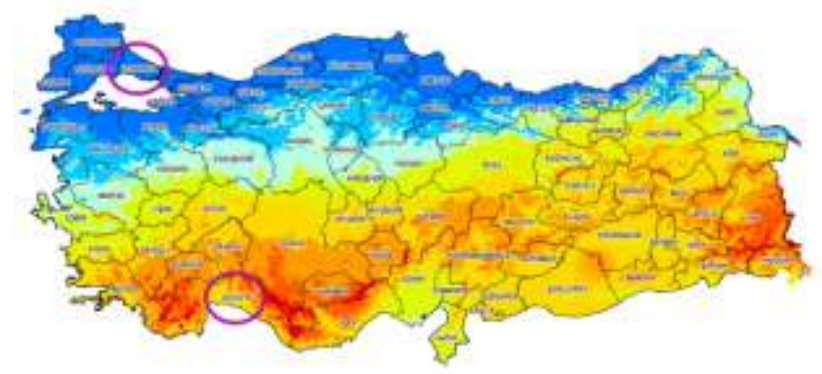

Fig. 3 Solar Energy Potential Atlas of Turkey

Sunlight duration and solar radiation of Istanbul and Antalya are given in Table 2.

Table 2 Sunlight duration and solar radiation of Istanbul and Antalya [11]

\begin{tabular}{|c|c|c|}
\hline Province & $\begin{array}{c}\text { Sunlight duration } \\
\text { (hours/year) }\end{array}$ & $\begin{array}{c}\text { Solar radiation } \\
\left(\mathrm{kWh} / \mathrm{m}^{2} \text {-year) }\right.\end{array}$ \\
\hline İstanbul & 2444.1 & 1612 \\
\hline Antalya & 3010 & 1646 \\
\hline
\end{tabular}

\section{Data used in HOMER}

In this study, the HOMER (Hybrid Optimization of Multiple Energy Resources) software has been used to evaluate design of grid connected PV systems having capacity of $3 \mathrm{~kW}, 4 \mathrm{~kW}$ and $5 \mathrm{~kW}$ in two pilot provinces. As an autonomous load the average daily consumption, $11.45 \mathrm{kWh}$ was determined for a four-person household. The daily load profile showing the hourly electric demand is given in Figure 4.

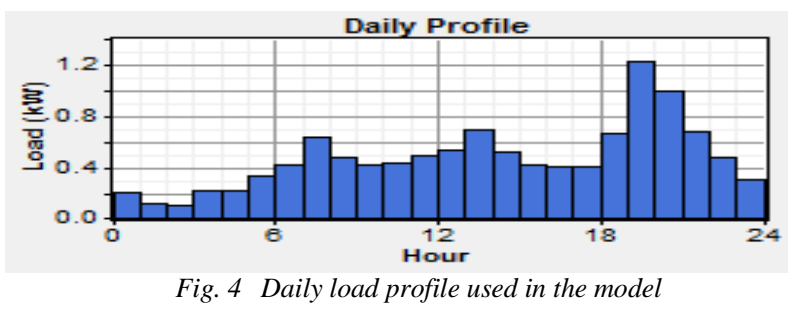

The seasonal profile used in the model is given in Figure 5.

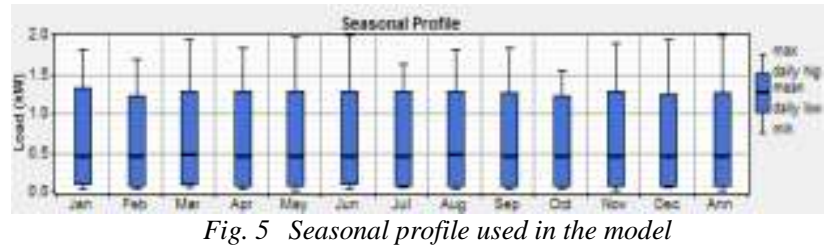

Schematic diagram of PV system components described in HOMER is given in Figure 6.

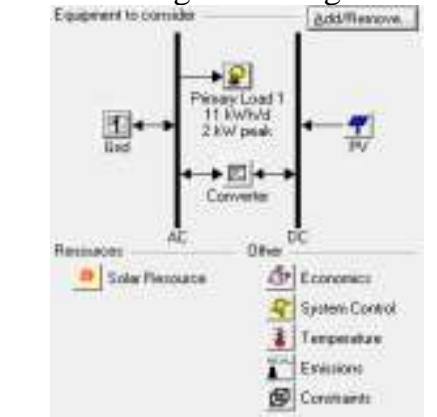

Fig. 6 Components of PV systems in HOMER

The use of storage battery was not considered since the photovoltaic systems in Istanbul and Antalya were designed as a grid-connected system. HOMER enabled to provide the radiation data of each selected province from Climatological Solar Radiation Data Sets of National Renewable Energy Laboratory (NREL) or NASA Surface Meteorology and Solar Energy Data Sets through internet connection [12].

Coordinates of selected provinces is given in Table 3 . The annual optimal angle of panel facing south is approximately equal to 0.9 multiplied by the latitude which are lower than $65^{\circ}$ [13]. Since Turkey is located in northern hemisphere, PV panels are fixed at south side of the roofs. Fixed angle of roof-top panels to be installed in Istanbul and Antalya have been calculated according to latitude (Table 3).

Table 3 Coordinates of selected provinces and fixed angle of panels

\begin{tabular}{|c|c|c|c|c|}
\hline Province & Regiod & $\begin{array}{l}\text { Latitude } \\
\text { (North) }\end{array}$ & Longitude (Soutth) & $\begin{array}{c}\text { Fixed angle of } \\
\text { panels }\end{array}$ \\
\hline Etamboal & Marmara & $4 a^{2} 59.91^{1}$ & $28^{\circ} 32.94^{2}$ & 36 \\
\hline Antalya & Moduterrarkan. & $36^{\prime} 5300^{\circ}$ & $30^{\circ} 42.36^{\prime}$ & 324 \\
\hline
\end{tabular}

Roof-top PV panels having capacity of $3 \mathrm{~kW}, 4 \mathrm{~kW}$ and $5 \mathrm{~kW}$ and inventers having same capacities (respectively) have been evaluated in HOMER. Initial 
capital cost of $3 \mathrm{~kW}$ PV systems is varying between 2610 EUR (3393 US\$) and 3960 EUR (5148 US\$) considering the investments in European countries including Germany, France, Greece and Italy [14]. Within the study, it was assumed initial capital cost is $1500 \mathrm{US} \$ / \mathrm{kW}$ and maintenance and operation cost is 40 US\$ for PV systems having capacity of $3 \mathrm{~kW}$. Initial capital cost of inventers has been identified as a result of marketing survey [15]. Initial capital costs of PV panels and inventers and maintenance-operation costs of the PV system are given in Table 4.

Table 4 Initial capital costs of PV panels and inventers and maintenance-operation costs of the PV system

\begin{tabular}{|c|c|c|c|}
\hline Capacity & $\begin{array}{c}\text { PV panel-capital cost } \\
\text { (USS) }\end{array}$ & $\begin{array}{c}\text { Inventer caputal } \\
\text { cost (US\$) }\end{array}$ & $\begin{array}{c}\text { Maintenance and } \\
\text { operational cont (USS) }\end{array}$ \\
\hline $3 \mathrm{~kW}$ & 4500 & 1500 & 40 \\
\hline $4 \mathrm{~kW}$ & 6000 & 1750 & 53 \\
\hline $5 \mathrm{~kW}$ & 7500 & 2350 & 66 \\
\hline
\end{tabular}

The lifetime of panels and inverters were assumed 20 years as well as project duration. Therefore, replacement cost has been not identified in the model. The efficiency of panels and inventers has been identified as $15 \%$ and $94 \%$, respectively.

In Turkey, the maximum feed-in tariff for generated electricity from solar resources is $20 \$$ cent $/ \mathrm{kWh}$ if the PV module and PV cell are produced in Turkey according to the Law on the Use of Renewable Energy Resources for Generating Electricity (Table 5) whereas 14.75 \$ cent/kWh is the electricity consumption price [16]. In the model, feed-in tariff was identified as $15.2 \$$ cent $/ \mathrm{kWh}$, because it was assumed the PV module and PV cell would be imported (not manufactured in Turkey).

In Turkey, feed in tariffs and incentives for local manufacturing are valid for 10 years and 5 years respectively. Validity of feed in tariffs in Germany, France and Italy are 20 years whereas 25 years in Spain. In the model, it was assumed the validity of feed in tariffs is 20 years in Turkey as well as other European countries.

\section{Results of Scenarios}

Istanbul has the highest solar radiation in Marmara Region as well as Antalya in Mediterranean Region in Turkey according to solar energy potential atlas (GEPA). Daily radiation and clearness index of Istanbul and Antalya obtained from HOMER are given in Figure 7.
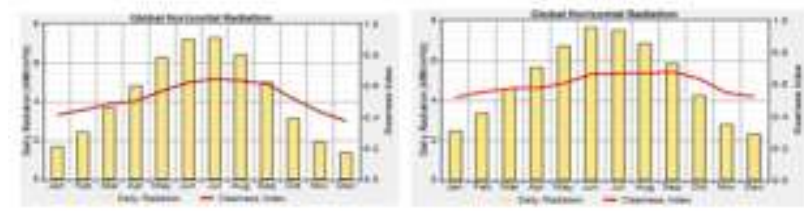

Fig. 5 Daily radiation and clearness index of Istanbul (left) and Antalya (right)

Monthly average electricity produced by PV systems having capacity of $3 \mathrm{~kW}, 4 \mathrm{~kW}$ and $5 \mathrm{~kW}$ and monthly average electricity purchased from grid in Istanbul and Antalya are given in Figure 8.

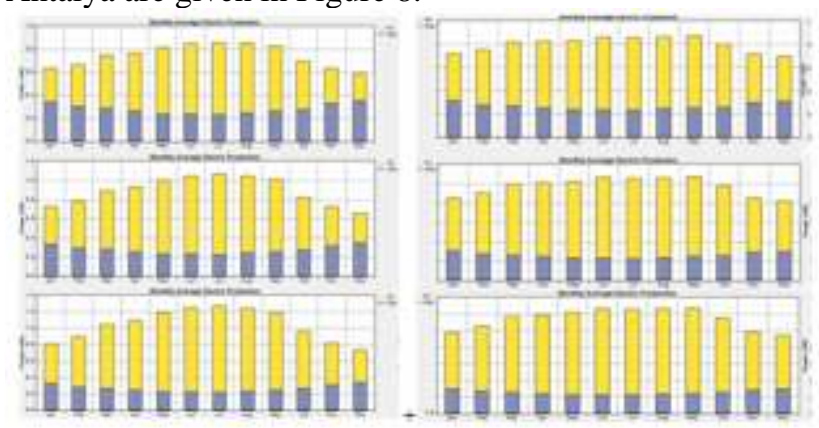

Fig. 8 Monthly average electricity produced (yellow bars) by $P V$ systems having capacity of $3 \mathrm{~kW}, 4 \mathrm{~kW}$ and $5 \mathrm{~kW}$ (from top to bottom) and monthly average electricity purchased from grid (blue bars) in Istanbul (left) and Antalya (right)

Results of HOMER regarding to current situation for PV systems to be installed in Istanbul are given in Table 5. The current initial capital costs of PV systems and current valid fees in tariffs in Turkey did not make PV systems investments attractive in Istanbul. The payback period of PV systems to be installed in Istanbul is varying between 16 to 16.8 years regarding to capacity of the systems.

Table 5 Results of HOMER regarding to current situation for PV systems in Istanbul

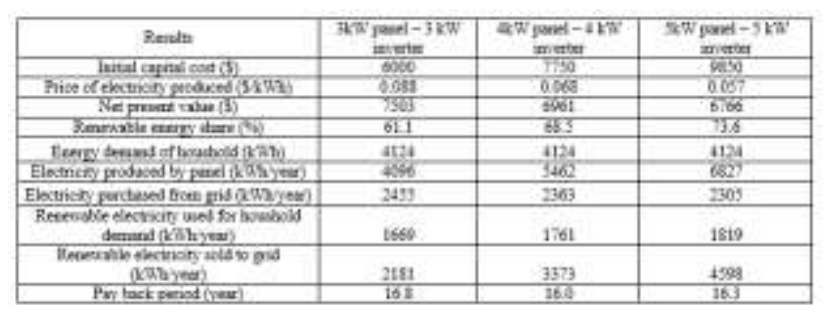

In order to decrease the payback period of PV systems investments, the scenarios including increase of $25 \%$, $50 \%, 75 \%$ and $100 \%$ in feed in tariffs have been evaluated. However, pay back periods did not result in below 7 years. Therefore, it was assumed that initial capital cost decreases $25 \%$ and feed in tariffs increase $25 \%$ and $50 \%$. Although payback period decreases, 7 years and below is not achieved in these scenarios. Evaluation results for PV systems to be installed in Istanbul have showed that payback period could decrease to lower than 7 years if the initial capital cost decrease 
A. Özkök, Ö. Güler
Economic Analysis of Domestic Electricity Production by Roof-Top Photovoltaic Systems in Two Provinces of Turkey

$50 \%$ and current feed in tariffs are applied. Scenario results for PV investment in Istanbul are given in Table 6.

Table 6 Scenario results for PV investment in Istanbul

\begin{tabular}{|c|c|c|c|c|}
\hline \multicolumn{2}{|l|}{ Rewots } & 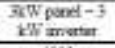 & 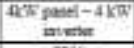 & 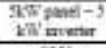 \\
\hline \multicolumn{2}{|c|}{ Iritul coptait sost (1) } & 6000 & 7756 & WESO \\
\hline \multirow{5}{*}{$\frac{\frac{\pi}{6}}{\frac{\pi}{8}}$} & Coerent uitsonce & 158. & 169 & 163 \\
\hline & 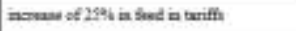 & 136 & 125 & 126 \\
\hline & 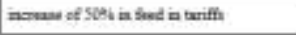 & 115 & 104 & 303 \\
\hline & 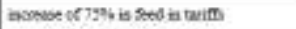 & $9: 9$ & 891 & 5.73 \\
\hline & 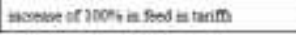 & $3 \pi$ & $T 78$ & $15 \pi$ \\
\hline \multicolumn{2}{|c|}{ 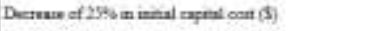 } & 4560 & 385 & 7900 \\
\hline \multirow{3}{*}{ क⿺辶一 } & 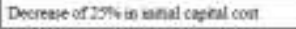 & 109 & 104 & 100. \\
\hline & 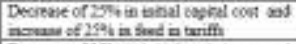 & get & 203 & 194 \\
\hline & 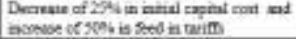 & 835 & 759 & 2.4 \\
\hline \multicolumn{2}{|c|}{ 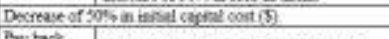 } & 3000 & 359 & 1929 \\
\hline $\begin{array}{l}\text { Pey bati } \\
\text { feilos }\end{array}$ & Decrene of 50 st in intix oseral cest & 0.4 & 42 & 631 \\
\hline
\end{tabular}

Results of HOMER regarding to current situation for PV systems to be installed in Antalya are given in Table 7. The current initial capital costs of PV systems and current valid fees in tariffs in Turkey did not make PV systems investments attractive in Antalya. The payback period of PV systems to be installed in Antalya is varying between 12.9 to 13.5 years regarding to capacity of the systems.

Table 7 Results of HOMER regarding to current situation for PV systems in Antalya

\begin{tabular}{|c|c|c|c|}
\hline Remen & $\begin{array}{c}\text { HeW/ panel-3KW } \\
\text { manter }\end{array}$ & 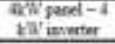 & 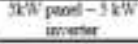 \\
\hline Irtial apinal cont (5) & 6000 & 7750 & 5650 \\
\hline 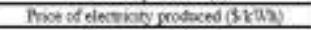 & 0.059 & 0.049 & 0,007 \\
\hline 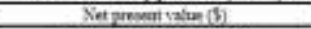 & 60 & 5 & 47 III \\
\hline 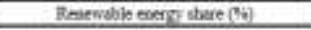 & 606 & 223 & $m 7.1$ \\
\hline 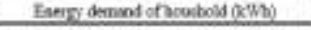 & 4124 & 424 & 4124 \\
\hline 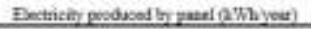 & 5780 & 0200 & 7809 \\
\hline 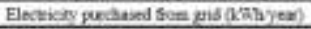 & 2918 & 224 & 2196 \\
\hline 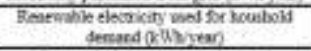 & 1906 & $13 \pm 3$ & 1023 \\
\hline 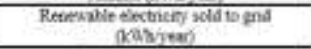 & 2821 & 4019 & 9459 \\
\hline For hack periad (yen) & 195 & 120 & 151 \\
\hline
\end{tabular}

In order to decrease the payback period of PV systems investments, the scenarios including increase of $25 \%$, $50 \%, 75 \%$ and $100 \%$ in feed in tariffs have been evaluated. If the feed in tariffs increase $100 \%$, PV systems investments having capacity of $4 \mathrm{~kW}$ and $5 \mathrm{~kW}$ can be considered feasible.

It was assumed that initial capital cost decreases $25 \%$ and feed in tariffs increase $25 \%$ and $50 \%$. Evaluation results for PV systems to be installed in Antalya have showed that payback period could decrease to lower than 7 years if the initial capital cost decrease $25 \%$ and feed in tariffs increase $50 \%$. Scenario results for PV investment in Antalya are given in Table 8.
Table 8 Scenario results for PV investment in Antalya

\begin{tabular}{|c|c|c|c|c|}
\hline \multicolumn{2}{|l|}{ Rerchs } & 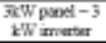 & $\begin{array}{l}\text { AKW' pasel-4KW } \\
\text { ianere }\end{array}$ & $\begin{array}{l}\text { SkW pent - } 5 \\
\mathrm{~kW} \text { irverter }\end{array}$ \\
\hline \multicolumn{2}{|c|}{ Intial capial cont (\$) } & 6000 & 7750 & 9350 \\
\hline \multirow{5}{*}{ 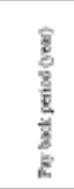 } & Curreat shustice & 135 & 129 & 131 \\
\hline & 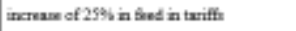 & 11 & 105 & 103 \\
\hline & incrawe of SDS in Seed in triff. & 9.32 & 8.55 & 8.47 \\
\hline & increase of $79 \%$ in treed in trims & 800 & 7.33 & 7.2 \\
\hline & increase of 1009 in sect in tarim & 714 & 6.2 & 6.23 \\
\hline \multicolumn{2}{|c|}{ 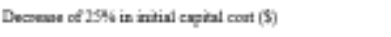 } & 4560 & s\$1s & 73200 \\
\hline \multirow{3}{*}{ 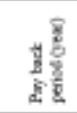 } & 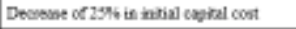 & 901 & 865 & 88 \\
\hline & 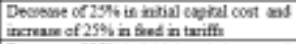 & 753 & 7.06 & 3.06 \\
\hline & 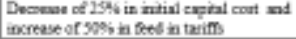 & 0.97 & 597 & 5.02 \\
\hline
\end{tabular}

\section{Environmental improvements resulted in photovoltaic systems to be installed in Istanbul and Antalya}

In Turkey, $\mathrm{CO}_{2}$ emissions per $\mathrm{kWh}$ from electricity generation has been identified as $472 \mathrm{~g}$ [17]. Considering environmental improvements, the PV systems having higher capacity should be invested instead of the PV systems having lower capacity although they have lower initial capital cost. The amount of $\mathrm{CO}_{2}$ emissions decreased by PV systems having capacity of $3 \mathrm{~kW}, 4 \mathrm{~kW}$ and $5 \mathrm{~kW}$ to be installed in Istanbul and Antalya is given in Table 9.

Table 9 The amount of $\mathrm{CO}_{2}$ emissions decreased by PV systems having capacity of $3 \mathrm{~kW}, 4 \mathrm{~kW}$ and $5 \mathrm{~kW}$ to be installed in Istanbul and Antalya

\begin{tabular}{|c|c|c|c|c|}
\hline Frotiuce & $\begin{array}{l}\text { Capacity of } \\
\text { the PV } \\
\text { system }\end{array}$ & $\begin{array}{l}\text { Consumed } \\
\text { electricity which } \\
\text { is produced by } \\
\text { PV ovotem } \\
\text { fowhyrat }\end{array}$ & $\begin{array}{l}\text { Sosd eloctricity } \\
\text { nhich is produced } \\
\text { by PV system } \\
\text { (kWh yean) }\end{array}$ & 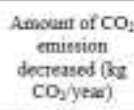 \\
\hline \multirow{3}{*}{ Istantrol } & $3 \mathrm{~kW}$ & 1669 & 2181 & 1817 \\
\hline & $4 \mathrm{~kW}$ & 1761 & 3373 & $2+25$ \\
\hline & $5 \mathrm{~kW}$ & 1819 & 4598 & 9028 \\
\hline \multirow{3}{*}{ Antzlya } & $3 \mathrm{~kW}$ & 18006 & 2621 & 2039 \\
\hline & $4 \mathrm{~kW}$ & 1833 & 4019 & 2785 \\
\hline & $5 \mathrm{~kW}$ & 1928 & 5450 & 3482 \\
\hline
\end{tabular}

\section{Results and Recommendation}

Within the study, two pilot provinces having the highest solar radiation in Marmara and Mediterranean region were selected according to solar energy potential atlas (GEPA). Roof-top photovoltaic systems with capacity of $3 \mathrm{~kW}, 4 \mathrm{~kW}$ and $5 \mathrm{~kW}$ were simulated by using HOMER software. As a result of this study, roof-top photovoltaic systems in Istanbul and Antalya was economically not feasible due to pay back period of around 16 years and 13 years, respectively. It was considered providing incentives mechanisms other than feed-in tariff and support programme especially regarding to roof-top PV systems could be a first step to decrease pay back periods in Turkey. The payback period of investments in each pilot province as varied that was resulted in difference solar radiation. Dissemination of PV 
A. Özkök, Ö. Güler

system in Turkey could be accelerated to apply higher feed-in tariff for provinces having lower solar radiation.

Regarding to environmental issues photovoltaic systems with capacity of $5 \mathrm{~kW}$ should be preferred which enable to decrease 3 tonnes of $\mathrm{CO}_{2}$ emissions and 3.4 tonnes of $\mathrm{CO}_{2}$ emissions per detached house in Istanbul and Antalya, respectively although their initial cost was higher than PV system with capacity of $3 \mathrm{~kW}$. Implementation of roof-top PV systems will be an important step to prevent global warming and reduce the dependence on fossil fuels.

\section{References}

[1] Electricity Generation Company (EÜAŞ). "Elektrik Üretim Sektör Raporu- Electricity Production Sectoral Report". $\quad$ Turkey. 2013. http://www.enerji.gov.tr/yayinlar_raporlar/Sektor_R aporu_EUAS_2013.pdf

[2] World Energy Council Turkish National Committee, "Enerji Raporu 2012 - Energy Report of 2012”. 2012 http://dektmk.org.tr/upresimler/enerjirapor2012.pdf

[3] Solar Energy Industrialists and Industry Association (GENSED). "Güneş enerjisinin önemi - The importance of solar energy" 2011. http://gensed.org/CF/CD/1285d8ef7b73342a5bbab1 3726efe23e48af1386245815.pdf

[4] Unlicensed Electricity Generation Association (LIDER), "Lisanssız Elektrik Üretimi Başvuruları Application for Unlicensed Electricity Generetion" 2014. http://www.lisanssizelektrik.org/lisanssizelektrik-uretimi-basvurulari/

[5] International Solar Energy Society -Turkey Section (GÜNDER). “Güneş Haber - News on Solar”. 2014. http://www.guneshaber.net/haber/2419-roportajlarturkiye39nin-gunesi-enerji39miz-olsun.html

[6] 5346 sayılı Yenilenebilir Enerji Kaynaklarının Elektrik Enerjisi Üretimi Amaçlı Kullanımına İlişkin Kanun - The Law No. 5346 on the Use of Renewable Energy Resources for Generating Electricity. Enerji Piyasası Düzenleme Kurumu. Turkey. 2005.
[7] 5627 sayılı Enerji Verimliliği Kanunu - Energy Efficiency Law numbered 5627. Enerji ve Tabi Kaynaklar Bakanlığı - Elektrik İşleri Etüt İdaresi Genel Müdürlüğü. Turkey. 2007

[8] Electricity Market Law numbered 5784 and dated 09/07/2008.http://www.resmigazete.gov.tr/eskiler/2 008/07/20080726-1.htm

[9] 6094 sayılı Yenilenebilir Enerji Kaynaklarının Elektrik Enerjisi Üretimi Amaçlı Kullanımına İlişkin Kanun - The Law No. 5346 on the Use of Renewable Energy Resources for Generating Electricity. Enerji Piyasası Düzenleme Kurumu. Turkey. 2011.

[10] The Law No. 6446 and dated 14/03/2013. http://www.eie.gov.tr/yenilenebilir/document/elektri k_piyasasi_kanunu.pdf

[11] Solar Energy Potential Atlas (GEPA). General Directorate of Renewable Energy. Turkey. 2014. http://www.eie.gov.tr/MyCalculator/Default.aspx

[12] HOMER Energy. "A New Look for HOMER News". 2011

[13] Chang, T. P. "The gain of single-axis tracked panel according to extraterrestrial radiation," Applied Energy, 86, 1074-1079. 2009

[14] Dusonchet L. and Telaretti E. "Comparative economic analysis of support policies for solar PV in the most representative EU countries," Renewable and Sustainable Energy Reviews, 986-998. 2014

[15] Solar Marketi Alternatif Enerji Ürünleri Marketi. "On-Grid Inverters (Grid-connected)". 2014. http://www.solarmarketi.com/On-Grid-InverterlerSebekeye-Bagli,LA_288-2.html\#labels=288-2

[16] Turkish Electricity Distribution Company (TEDAŞ). "01/01/2014 Tarihinden Itibaren Uygulanacak Fonsuz Tarifeler". 2014. www.tedas.gov.tr/BilgiBankasi/KitaplikElektrikTari feleri/Tablolar.xls

[17] International Energy Agency. "IEA Statistics. CO2 Emissions from Fuel Combustion Highlights 2013 Edition".2013.

http://www.iea.org/publications/freepublications/pu blication/co2emissionsfromfuelcombustionhighlight s2013.pdf 